\title{
How Much is Enough?
} Dialing in Irrigation on Northeast Diversified Vegetable Farms

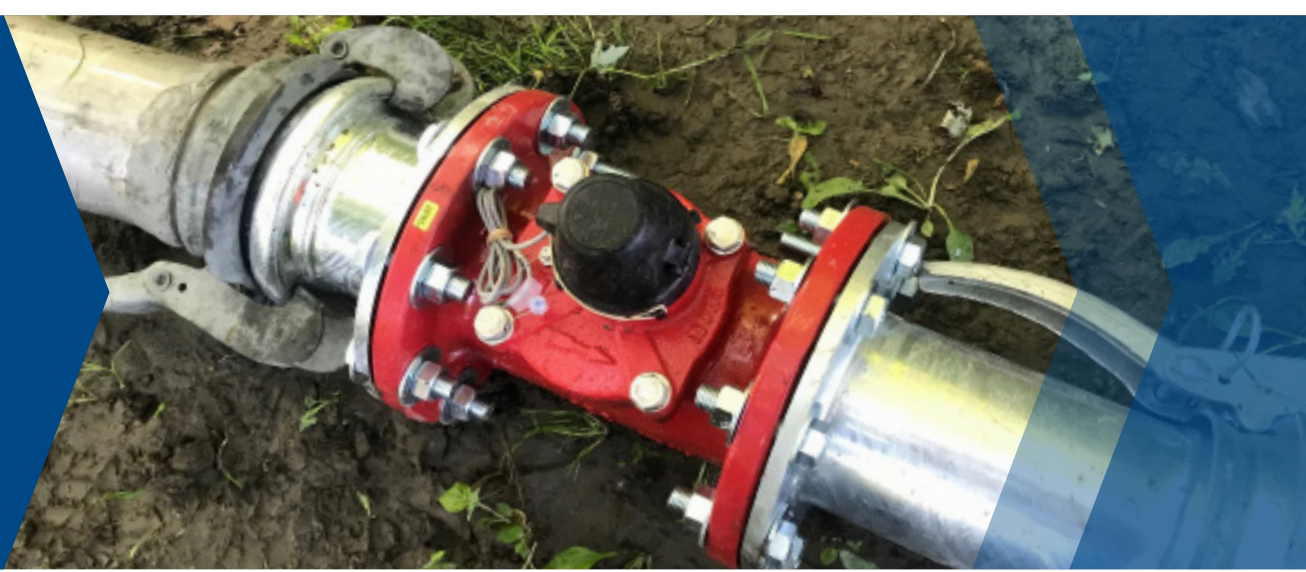

Researchers and farmers work towards efficient irrigation by comparing crop water needs to weekly applications on diversified vermont vegetable farms

by Dr. Rachel E. Schattman and Dr. Joshua Faulkner - January 2019

\section{Overview}

Water-use efficiency is an important part of sustainable vegetable production. Applying the right amount of water helps to maximize crop yields and quality ${ }^{1}$. Over-application of water leaches nutrients away from the root zone. These nutrient losses cost farmers money and can impair public waterways ${ }^{2}$. Shifting rainfall patterns associated with climate change have led to periods of either too much rain or too little rain. These abrupt shifts from wet to dry conditions sometimes occur in the same growing season ${ }^{3}$. Two strategies for enhancing water-use efficiency are using soil moisture sensors, and matching water applications to crop water needs.

In 2017-2018, researchers from the USDA Northeast Climate Hub and University of Vermont (UVM) Extension set out to understand the irrigation practices of Northeast vegetable producers, and whether or not those practices could be improved. This was done in two stages.

First, the team conducted a survey of on-farm water use in partnership with the University of Massachusetts Amherst. The survey targeted vegetable growers in Vermont and Massachusetts. Second, the team installed flow meters on two farms in northern Vermont to track irrigation water withdrawals on a weekly basis. Flow data was combined with rainfall rates collected from a nearby weather station and long-term average evapotranspiration rates for the area from the NOAA Northeast Regional Climate Center. Water balance calculations allowed the researchers to estimate whether farmers were applying enough water to meet crop needs. In addition, the team installed soil moisture sensors on one of the farms. They did so to test the usability of this technology for enhancing irrigation efficiency in a highlydiversified cropping system.

\section{Survey Results}

The water use survey was conducted in the winter of 20172018. It targeted subscribers to the Vermont Vegetable and Berry Growers Association (VVBGA) electronic mailing list and the UMass VegNotes Newsletter. There were an estimated 2,167 farmers on both lists combined. The researchers collected responses from 155 vegetable growers (26 partial and 121 full responses).*

The majority (90\%) of survey respondents reported using water for irrigation at least one time in 2017. The most common irrigation approach among respondents was drip/ trickle irrigation (an efficient mode of application), with some respondents reporting use of overhead sprinklers (stationary or traveling). The majority of respondents drew from more than one type of water source for irrigation. Deep wells, rivers, and municipal water sources were commonly reported. The majority of respondents using "plant condition" $(89 \%)$ as their cue to irrigate. Unfortunately, crops that experience water stress have a reduced yield ${ }^{4}$. This led the researchers to hypothesize that many survey respondents under-irrigate crops. To test this hypothesis, they developed a plan for two on-farm case studies.

\footnotetext{
*The response rate for $V V B G A$ members was $10 \%$, the response rate for VegNotes subscribers was $1 \%$, and the combined response rate was $5 \%$. Because of low response rates, the results that we report from this survey should be interpreted as indicative of survey respondents only, and should not be generalized to the greater population of vegetable producers in the Northeast.
} 


\section{On-Farm Case Study Results}

By tracking irrigation water use on two Vermont farms during the 2018 growing season, the researchers found that farmers both over- and under-irrigate their crops. Farm A, located in Addison County, grew 30.5 acres of mixed vegetables. The soil type was a fine sandy loam. Irrigation water was drawn from two sources (a stream and a brook), which were both reliable throughout the season. The farmer utilized overhead irrigation on 26.5 acres, and drip irrigation on 4 acres. The team installed separate flow meters on each irrigation system. They also installed soil moisture sensors (tensiometers) within several crops around the farm, which provided the farmer and the researchers real-time data on soil moisture. Farm B, located in Chittenden County, grew 20 acres of mixed vegetables. The soil type was a fine sandy loam. Irrigation water was drawn from a river, which was reliable throughout the season. The farmer utilized a mix of overhead and drip irrigation on 15 acres. The researchers installed a single flow meter on the irrigation system.

The team found that on Farm A, water was over-applied in zones that used drip irrigation and under-applied in overhead irrigation zones (figures 1 and 2). The green line in both figures shows the difference between the water the crop needs and the water that is available. A negative value shows a shortfall, and ideally a farmer would irrigate when the water depth fell below 0 inches. Data collected from the soil moisture sensors also supported this finding. In general, these sensors provide insight into soil moisture deficits and surpluses. Soil moisture deficit is defined as the amount of rain (or irrigation) required to raise soil moisture content to field capacity. The amount of irrigation water applied, if done correctly, should be roughly equivalent to the soil moisture deficit in order to raise soil moisture content to field capacity. Mid-season results shared with the host-farmer led to a quick management adjustment to water applications. Farm B also over-irrigated, though by a smaller margin The research team plans to work with Farm B in 2019 and track water applications in smaller zones. This will help them pinpoint areas where water-use efficiency can be improved even further.

The results of these case studies suggest that water-use efficiency can be improved in Northeast vegetable operations. Tracking water use (with flow meters) and using soil moisture sensors to schedule irrigation are two approaches for enhancing water-use efficiency. The research team found that, while irrigation is widely used on vegetable farms, few growers invest in, and rely upon, soil moisture sensors to schedule irrigation. Many farmers over-irrigate (leading to nutrient leaching) or under-irrigate (leading to decreased yields/quality). Better information about soil moisture conditions, tailored to the scale and diversity of Northeast farms, can greatly improve irrigation efficiency while protecting water quality and supply in an era of climate change.
Figure 1

Under irrigation in over-head irrigation zone on Farm A. The green 'Deficit' line, when below zero, indicates that crops were often not receiving adequate water.

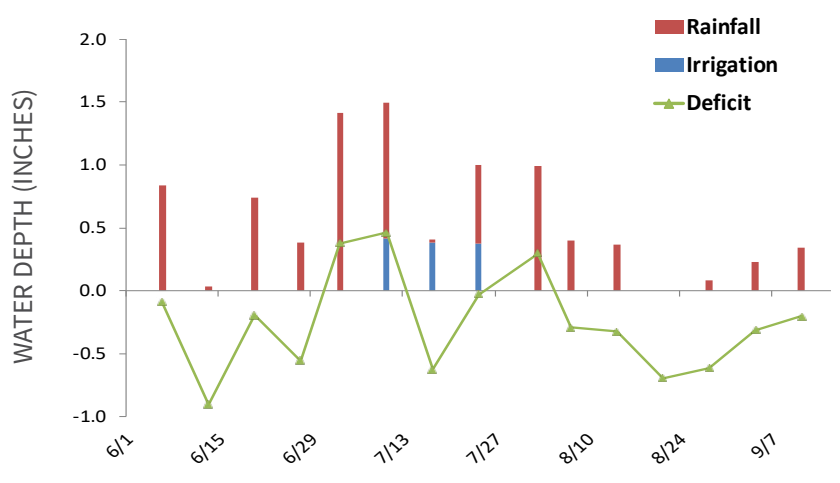

Figure 2

Over-irrigation in drip irrigation zones on Farm A. The green 'Deficit' line, when above zero, indicates that crops were often receiving water in excess of plant needs.

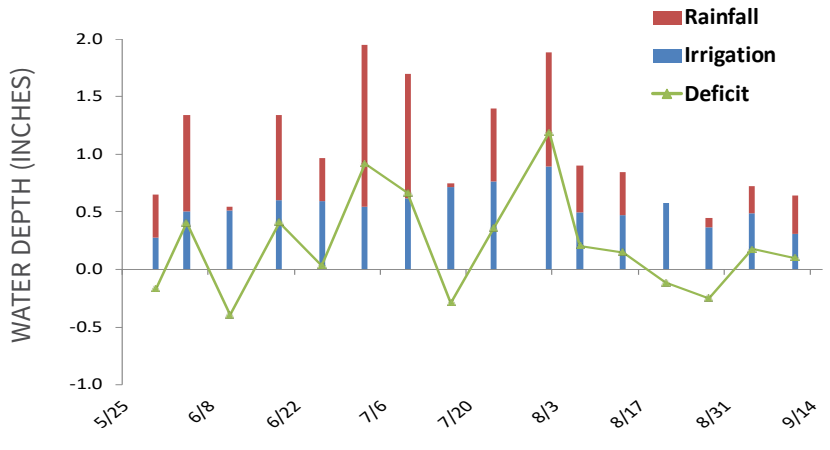

\section{REFERENCES}

${ }^{1}$ Imtiyaz, M., Mgadla, N. P., Chepete, B. \& Manase, S. K. Response of six vegetable crops to irrigation schedules. Agric. Water Manag. 45, 331-342 (2000).

${ }^{2}$ Brooks, B. W. et al. Are harmful algal blooms becoming the greatest inland water quality threat to public health and aquatic ecosystems? Environ. Toxicol. Chem. 35, 6-13 (2016).

${ }^{3}$ Wolfe, D. W. et al. Projected change in climate thresholds in the Northeastern U.S.: Implications for crops, pests, livestock, and farmers. Mitig. Adapt. Strateg. Glob. Chang. 13, 555-575 (2008).

${ }^{4}$ van Loon, C.D. The effect of water stress on potato growth, development, and yield. American Potato Journal. 58, 1-69 (1981).

\section{ACKNOWLEDGEMENTS}

Vern Grubinger and David Hollinger provided guidance on project de sign. The Vermont Vegetable and Berry Growers Association provided conceptual input and financial support.

\section{FOR MORE INFORMATION ABOUT THIS ONGOING RESEARCH}

RachelE.Schattman: rachel.e.schattman@usda.gov

Joshua Faulkner:joshua.faulkner@uvm.edu

IMAGE CAPTION/CREDIT

Flow meter installed on a 6" irrigation line in Burlington, Vermont. Photo by Rachel E. Schattman 